\title{
THE ADVANTAGES OF USING DIGITAL 3D ANIMATION IN GEOMETRICAL EDUCATION
}

\author{
A B S T R A C T
}

New media technologies and interdisciplinary approach is used and represented in this paper. The aspects and research results are shown through the production methodology, multimedia learning tool and the final application in geometrical education. The method we used here is obtained from overlapping of multiple disciplines such as architecture, structural systems, descriptive geometry and computer animation. Geometrical construction is presented on visual dynamic educational device for students of technical and applied arts faculties. Multimedia DVD is named: "Geometrical education by using 3D animation principles and tools". Geometrical education enables development of the understanding and perception of space as well as the ability of spatial representation. Drawing is not the goal of geometrical education. Our aim is to simplify the perception of geometrical construction, and by the method is proposed in this paper it is quite possible.

\author{
Aleksandar Čučaković \\ University of Belgrade - Faculty of Civil Engineering \\ Biljana Jović \\ University of Belgrade - Faculty of Forestry
}

KEY WORDS

GEOMETRICAL EDUCATION

3D ANIMATIONS

VISUALISATION

3D SOFTWARE DEVICES 


\section{INTRODUCTION}

The aspects and research results dealing with changes in the way of teaching geometry and the directions of transformation that are in accordance with modern technological requirements and needs are given in this paper.

The paper deals with the perception of space, 3D space, describing the monocular and binocular mechanisms of perception, while the focus is on the binocular mechanisms of the perception of 3D space. The binocular mechanism of the 3D space perception is crucial for stereoscopy.

The structure and training of spatial abilities have the basis in the theory of constructive geometry as well as founding explanation through pedagogical theory - constructivism. Pedagogical constructivist theory provides a valid and reliable basis for the theory of learning in a virtual environment. Pedagogical tendencies for the systematisation of the contemporary geometrical education could be seen through the development of 2D dynamic geometric software that led to the development and improvement of 3D dynamic geometric software with the focus on the application of multimedia in geometrical education. In this paper, we have proposed the systematisation of the software that is currently in use for geometric education.

The implementation procedure and the process of creating a short animated form are presented on the multimedia DVD that contains 16 short animated forms with concise textual explanations - the titles are described.

Multimedia DVD titled "Geometric education using principles and tools of 3D animation" is a teaching material intended for geometrical education of students of technical and artistic group. The treated geometrical areas are grouped into the following: Plato's solids; Ruled surfaces; Rotational surfaces; Sections and intersections of geometrical solids; Experimental design (free form). In the framework of Plato's solids there are 4 multimedia: cube and hypercube; tetrahedron and octahedron; pentagonal dodecahedron and icosahedrons. Within the framework of the ruled surfaces, the multimedia deals with: conoid, hyperboloid; helicoid and hyperbolical paraboloid. The rotational surface is treated through torus. The sections and intersections of geometrical solids are multimedially represented through: conic cross-sections, intersection of the cone and cylinder, intersections of spheres and cylinders and intersections of two semicylinders. Special attention is paid to the experimental design (free form) where there are three multimedias titled: lattice deformer; duplication along the curve and profile with two guides (birail tool). ${ }^{1}$ These three short animated forms indicate the possibility of experimentation related to free forms, 
using 3D animation applications that are practicaly infinite. Dynamic geometric education is dominant here, the possibility of experimenting is practically unlimited. A special advantage is the ability to get to the desired form. At the time of finding the solution, the choice is made by subtracting a dynamic component and, if necessary, by creating a physical model according to the procedure of $3 \mathrm{D}$ model production.

\section{METHODS}

The interdisciplinary approach in the use of digital technology is the basic device in this paper. Nowadays, not only interdisciplinary but transdisciplinary or hybrid approach is commonly used. This kind of open approach allows changes in the categorisation of education and digital definition itself. The focus is on the fusion of different media and genres into new forms of expression. Transcending the boundaries between art and science, art and education, the arts and research, lead us to transdisciplinary approaches. The area that is the most suitable for this method is the implementation of virtual technology which refers to the use for the dynamic education. Live recording of the whole construction process of the geometry in 3D software resulted in the dynamic geometrical educational tool. The animations that are done are subtitled with short explanations. The whole process was done in the Studio for digital 3D animation at the Faculty of Architecture, University of Belgrade. The software for 3D animation Autodesk Softimage was donated by USAID to the Faculty of Architecture, University of Belgrade in 2007. Dynamic and interactive animation programs for the study of geometry improve the development of spatial visualisation ability and overcome the geometry perception problem. ${ }^{2}$

The causality induction method - the detection of cause-effect connections is based on the principle of causality from individual to general. Individual objects or phenomena, are not only found in the immediate relations of existence but also have multiple connections with other objects or phenomena.

One phenomenon (for example, motion) causes another, one solid determines the other and similar. The explanation for applying this method is through a short animated form of dynamic geometrical education. Certainly, one of the most effective ways to acquire geometric knowledge is visualisation and modelling of objects in different dimensions (2D, 3D, 4D). Using CAD/CAM/ $\mathrm{CAE}$ as well as virtual technologies, it is possible to inspect the construction of the building from all sides, as well as the possibility of exploring the space. ${ }^{3}$ 
The dynamic component is of crucial importance in geometric education because it enables a good training of users' spatial capabilities. The areas of application of methodological innovations are in the field of geometry of space and application of virtual technologies (VT) with a focus on geometric education in the field of visualisation and experimental design. The use of the visualisation tools that involve the application of graphic software - interface links to the data presented and the corresponding information. Computer visualisation produces images to present the desired data. Then the images are animated, and the final result is a multimedia DVD containing 16 short animated films dealing with different geometric areas followed by short textual explanations.

\section{RESULTS}

Knowledge dealing with spatial relations, classification and ranking of spatial relations, transformation and rotation relations between the parts and a whole of space is involved in space perception. The term visualisation means, the ability to present data or object so as to be visible as well as, the ability to create a mental picture of the same. Thus, the visualisation signifies the process of converting data or objects into a perceptible form for the brain or imagination. ${ }^{4}$

Using visual techniques: images, colours, charts, and animations illustrate a certain scientific field, which does not need to be based on visual or could only be seen using technical aids. The visualisation of spatial structures and spatial perception is included in the geometrical education.
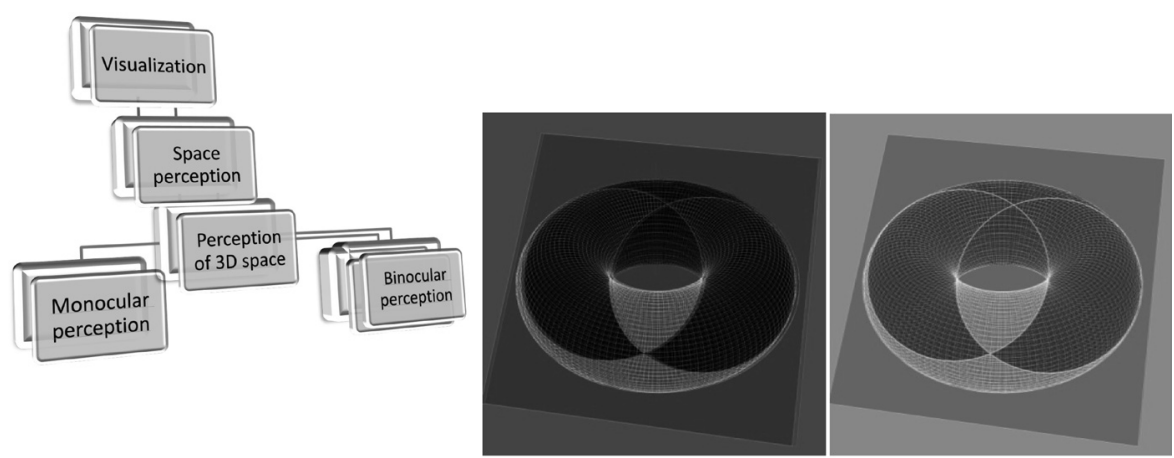

Figure 1. The combination of research areas within the visualization with example of changing background in stereoscopic rendering 
Perception is defined as the process of interpreting sensations and events with the influence of previous experiences that in this way gain meaning. Perception implies the organisation of a sensory input in a meaningful experience that in this way acquires significance. ${ }^{5}$ Visual perception is defined as the tendency of individual consideration of meaningful content where the result is a unique experience. ${ }^{6}$

A particular feature of visual perception is the ability to capture 3D space (Fig. 1). Under the capability of perceiving a $3 \mathrm{D}$ space, the possibility of estimating the relative distance between the objects, as well as the inner sense of the shape of the form, or the third dimension of the space is assumed. ${ }^{7}$

A linear or linear perspective that uses only one projection center gives fewer images than a stereoperspectivity that uses two projection centers. There are two basically and essentially different groups of mechanisms of perception of 3D space: monocular and binocular physiological mechanisms. Geometry of binocular vision is the basis for the creation of a three-dimensional perception of steroscopy and stereograms. ${ }^{81}$

\section{Monocular Perception}

Monocular mechanisms of three-dimensional perception represent only auxiliary physiological functions. They are significant but are not the key to making a stereoscopic impression.

The monocular mechanisms of three-dimensional perception include: differentiation of the relative sizes of the observed objects, apparent overlaps, linear perspective, relative ratio of warm and cold colors, relative contrast ratio, relations of light and shadow and parallax of monocular shift. Distinguishing the relative magnitude of the observed objects - the relative magnitude of the percipated image allows estimating the distance based on the past and present experience of the dimensions of the observed object. If the observed object leaves the observer, its image on the retina decreases, and the comparison of relative and consecutive images creates an impression of the depth of space. The apparent overlapping of the retinal images of the observed objects induces the impression that the folded objects are located farther from those overlapping them. Linear perspective - the retinal picture of the observed objects, in the first approximation, has the properties of a linear perspective, or a central perspective of space. The appearance of the vanishing points and vanishing lines creates an impression of the depth of space. This impression has, without any doubt, origin in experience. The relative relation of warm and cold colours - the relative relation of the colours of the observed objects 
induces a certain impression of their distance, or the impression of their mutual spatial disposition. The origin of this perception probably arises from the experiential knowledge that the distant objects have a colder (bluish) shade, while the closer have a warmer (reddish) shade. These empirical facts are explained by the physical law that, in air layers, the light of larger wavelengths decomposes more intensively (Rayleigh scattering). The greater the passage of white light from the subject to the observer's eye, the more intense scattering of its warmer shades. Relative contrast ratio - a visible impression of the contrasts of the observed objects can also contribute to the general sense of depth of the observed space. The dispersion of light rays of all colours is more intense if these rays exceed larger distances through the air layers. For this reason, the impression is created that visible loss of detail in distant objects become blurred and unclear. Light and shadow relations: a clear impression of the relationship between the illuminated and shaded surfaces of the observed objects as well as the positions of their thrown shadows also make a significant contribution to the general perception of space.

Paralysis of the monocular movement - if the observer takes a view to the left and right, a visible impression is created that objects at different distances move at different relative speeds. The impression is that closer objects move to the opposite side from the direction of the observer's movement and farther to the same. This phenomenon, to a certain extent, forms the impression of the spatial distance of the observed objects.

\section{Binocular Perception}

Binocular mechanisms are key to creating deep perception of 3D space stereoscopic. True stereoscopy cannot be formed on the basis of one image or on the visual impression of one eye. In order to comprehensively understand the complex physiological mechanism of binocular perception, it is necessary to completely clarify the phenomena: binocular retinal disparity, fusion; convergence, Panum's fusion surface, suppression, superimposition and binocular rivallity. Binocular retinal disparity - when the same object is viewed binocular, then two different retinal images are formed on the meshes of each eye. The differences in the geometric and other characteristics of central projections of the same space on the retina of each eye from the binocular pair are called the binocular retinal disparity. The described retinal disparity is essential for binocular stereoscopy. The term fusion implies a process that takes place in the central nervous system. It is the process of combining two different retinal images into one unique impression. The fusion overcomes retinal disparity and is only possible when both eyes observe the same subject under certain physiological conditions. The crucial consequence of the fusion of two different 
retinal images is the sense of the three-dimensional perceived space. If there is no fusion, there are phenomena to which the central nervous system overcomes confusion, such as: suppression, superimposition, and binocular rivallity. Suppression is a phenomenon of eliminating one retinal image in a binocular pair, in order to overcome potential confusion. It is a physiological mechanism that takes place unconsciously or partially consciously in the central nervous system. The retinal suppression of the left or right eye is possible depending on which brain sphere is more active. Superimposition is the phenomenon of insertion of an image that occurs on the retina of one eye through the retinal image of the other eye. It is a physiological process of the central nervous system that overcomes confusion when fusion and suppression are disabled. Binocular rivalry is the name for the phenomenon of alternative suppression. When the central nervous system is unable to achieve either suppression or superimposition of the corresponding retinal images, it goes into the state of ambivalence and performs alternate suppression and expression of images from one and the other retina, alternately. The term convergence in binocular stereoscopy implies the non-parallelism, or the intersection of optical axes in the case of close-up objects. In general, the optical axes of both eyes are cut infinity, whereas only in the case when the horizon is visible, than the optical axis is parallel. This effect is detected and processed in the central nervous system, which to a certain extent contributes to the creation of the impression of the spatial distribution of the observed objects. This physiological phenomenon is effective exclusively for relatively small distances due to a small interocular distance. The convergence of optical axes contributes to binocular stereoscopy when observing objects located at a distance of less than 3m. Panum's fusion surface is a zone on the retina of the eye in which fusion is possible and in which retinal disparity produces a unique stereoscopic perception of space. Panum's fusion surface is a region of binocular monofocal vision. Out of Panum's fusion surface there is a physiological diploya. The diploya occurs when visual axes come to an outstanding position, causing the images of the observed object to reach the irrelevant surfaces on the retina of each eye. Then, instead of one image, the impression of perception are two images. Normal binocular vision results from brain fusion slightly different from the image given by each individual eye, with the centre on the retina and both eyes correspond with the retina. A binocular diploya occurs when the eyes are not properly oriented, so the image of an object appearing on one retina does not fall to a spatially appropriate point on the other retina. In this situation, a double image is eliminated if one eye is closed. So we could conclude that binocular mechanisms are key to creating deep perception of $3 \mathrm{D}$ space. 
The ability to perceive 3D space is a special feature of visual perception. The possibility of estimating the relative distance between the objects, as well as the internal sense of the shape of the form, or the third dimension of the space, is assumed to be capable of perceiving a 3D space.

Dynamic Education of Descriptive Geometry by 3D Digital Animation

The main reason why the chosen geometrical topics are presented as short animation forms with a concise textual explanation because of the abovementioned facts related to perception of space. A higher degree of visualisation in education is scientifically based on the theory of stereoscopic projections as well as in the theory of collinear transformations. The theory of stereoscopic relies on the theory of perspective collineation and the methods of projective - synthetic geometry. The fulfillment of the expected results include a move towards a simpler and more efficient educational process.

The applicability of 3D dynamic geometry in education makes it possible to improve spatial capabilities, ease of use, pedagogical motivation for users in terms of encouragement for deeper geometry research and the possibility of consistent sustainability. The possibility of visualisation with multimedia integration into the current geometric education, where the dynamic component of education is emphasised, enables the development of user spatial capabilities. The proposed form of educational environment represents a new potential for studying geometry and integration of multimedia in contemporary geometrical education.

Animation in a virtuous environment enables the implementation of complicated operations as well as analysis of different spatial configurations. By moving through the space (Virtual Reality, Augumented Reality - Iotracker system and Mixed Reality), designers explore the interactions between objects in different ways and from different positions. ${ }^{9}$

Contemporary computer graphics applications create an environment where it is possible to achieve the interactivity of $3 \mathrm{D}$ objects that traditional approach does not allow. The advantage of this method is in developing the project before entering the serial production phase, the shortcomings can be noted in time without investing in physical models and investing in test elements. This method is different from modeling and constructing using coordinates in $3 \mathrm{D}$, using the application for 3D animation for multimedia creation. The application of the results of this paper is in the field of geometric education as well as scientific research in the methodology of design dynamically generated forms. 
3D dynamic geometry in education have applicability in upgrading of spatial ability and ease of application. Also, pedagogical stimuli for users in terms of encouragement for the further geometry exploration are stressed.

In this paper the topology is actually analysed by analysing the geometry of 3D models for animation. Topology refers to the number of points represented by vertex/vertices and the way they are connected, as well as geometric characteristics of mesh of the 3D objects. Smoothing algorithm on the polygonal objects have importancy in topology. Modelling of the objects that should be animated is the most demanding part of the process. One other important requirement is to have the regular deformations, and that is the next task that topology should fulfill.

Multimedia teaching material for 3D geometrical education is done by using character animation. The main reason why the work is presented as short-form animations with concise text explanations is because of the well known facts related to the perception in the geometrical education. ${ }^{10}$

\section{DISCUSSION}

The dynamic component of the animated multimedia contributes to development of the spatial ability. New potential for the study of geometry is represented by this kind of educational environment.

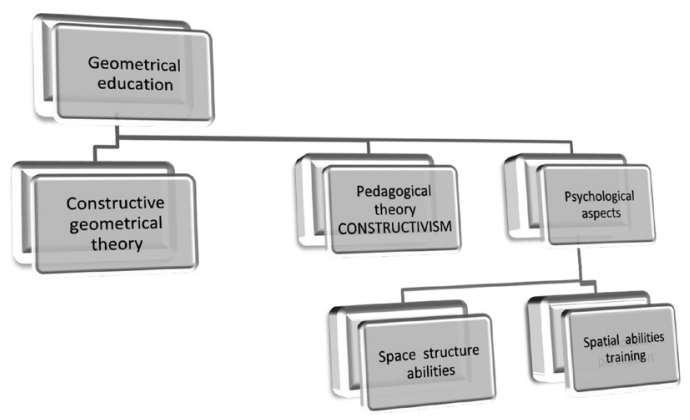

Figure 2. Components of geometrical education 


\section{Teaching and Learning Using Digital 3D Animations}

The aim is to provide the successful implementation of a new experience of learning in a way that the flexible learning path must be provided. Integration of the known types of information and educational support, different from the $3 \mathrm{D}$ presentation, such as audio and text comments and images is included. Also, it is important to carefully define the specific tasks for the students through interaction with the teacher. Numerous authors suggest that using different models of learning in a virtual environment from autodidactic learning models to those who are guided by teachers.

There are numerous areas of 3D animation: parametric animation, character animation, medical and other scientific visualisation. Parametric animation include visualisation based on mathematical functions. Dynamic simulation is based on the laws of physics. Character animation is used in our research.

Geometric education relies on the theory of constructive geometry and pedagogical theory - constructivism. Psychological aspects of the geometrical education involve the structure and training of spatial abilities. (Fig. 2)

The systematisation of the theory of geometric regions that would fully satisfy the needs of fine geometric education is proposed (Fig. 3). The conventional way of teaching, which involves drawing with free hand using ruler and compass on paper is suggested for the following areas: the relations of a point, line and plane, construction of orthogonal projections of geometrical objects, construction of axonometric projections, elements of topographic projections and basic elements of the perspective projections. In this paper, it is considered

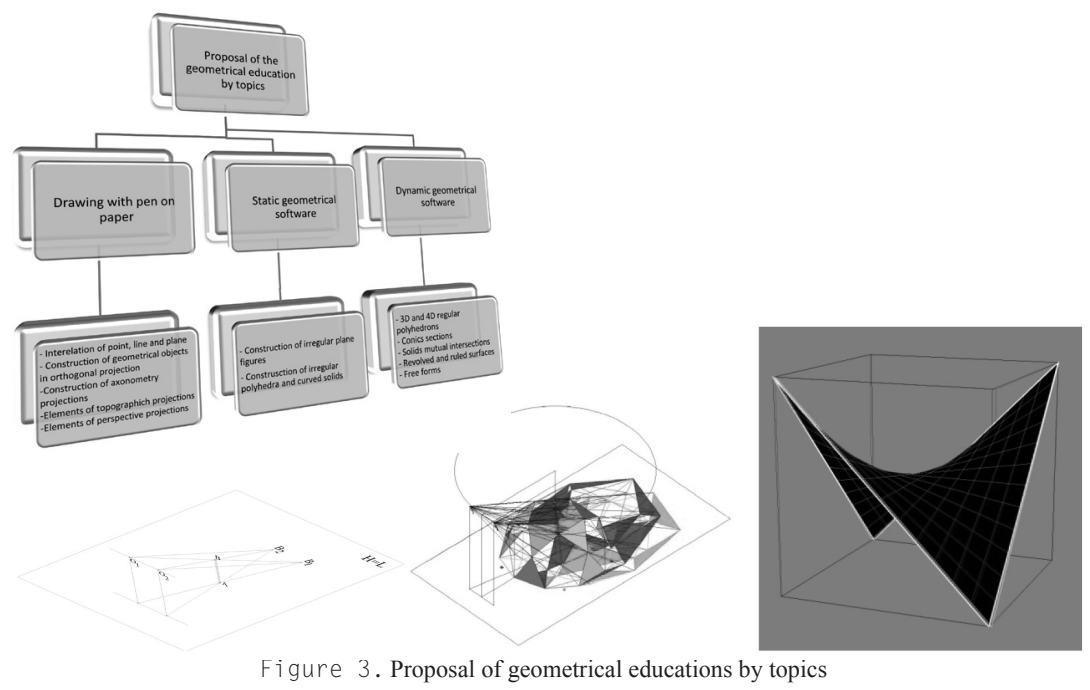


that static geometric software should handle the following areas: construction of irregular plane figures, construction of irregular polyhedra and curved solids. Dynamic geometric software is proposed for education in the topics: 3D and 4D regular polyhedral, conical sections, mutual intersections of polyhedra and curved solids, rotation and ruled surfaces and free forms.

Pedagogical tendencies for the systematisation of contemporary geometrical education could be seen through the development of 2D dynamic geometric software that lead to the development and improvement of $3 \mathrm{D}$ dynamic geometric software with the focus on the application of multimedia in geometrical education while the direction of further research areas is related to virtual reality (Fig. 4). Numerous studies show that the spatial abilities of students are enhanced by free-hand drawing integrated into geometric education. ${ }^{11}$ Computers are suitable for solving much more complex tasks that require a lot of time to be manually drawn. The use of computers, in particular the use of geometric dynamic software, offers new opportunities to gain insights into geometric problems. Particularly important is the introduction of multimedia in the teaching process for numerous benefits for students and teachers. The combination of geometric manual drawing of sketches, educational CAD programs and dynamic geometric software is the basis for the developement of the methodology in geometrical education. ${ }^{12}$

The proposal that is given in this paper is based on research we conducted for the systematization of dynamic software for geometrical education represented in Fig. 4.
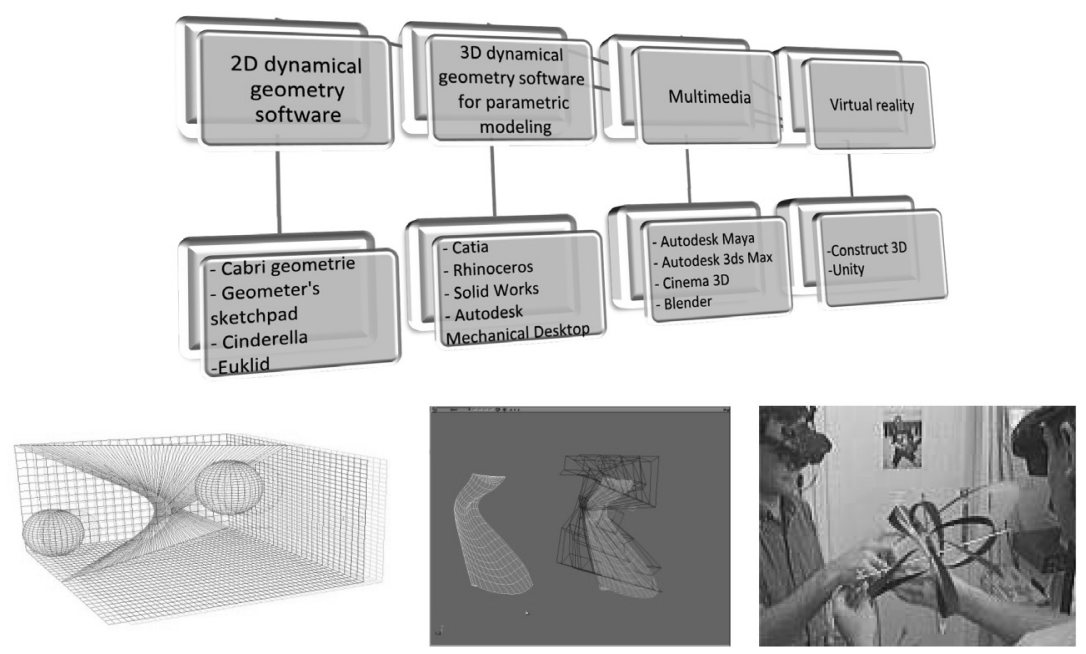

Figure 4. Proposal of using software for geometrical education 


\section{Dynamic 2D Geometrical Software}

The beginning of geometric dynamical education went through the application of 2D geometric software. Since computers can record the way we construct geometrical objects, the software is able to rebuild the structure after changing certain parametres. This is the key concept of dynamic geometry: a point is chosen to change the position, and changes in the design are currently visible. This ability is fundamentally an improvement over drawing on paper or static CAD models. Comprehensive work on dynamic geometry was explained by Kortenkamp in "Foundation of Dynamic Geomery", ${ }^{13}$ where the importance of the fact that the behavior of the geometric construction could be researched in movement is explained for educational purposes. It could be noticed which parts of the structure is changed and which parts remained the same - unchanged. Far more insight into the specific construction is obtained and general geometry is much clearer if we can experience what happens when you start moving the construction. More sophisticated software provide another additional understanding and explanation supporting the location and traces of the movement of the object that is dynamically adjusted.

The first software packages for dynamic geometry that date back to 1988 are Cabri Geometre ${ }^{14}$ and Geometer's Sketchpad ${ }^{15}$ from 1989. Since then, much has been done to introduce dynamic geometric software into education. The most popular are Cinderella ${ }^{16}$ followed by Euclid ${ }^{17}$ and Geometer's Sketchpad as well as Cabri Geometre.

\section{Dynamic 3D Geometrical Software}

Virtual technologies are a contemporary and easily accessible interactive visualisation tool. With the development of modern technology, they have become a common tool in education, initiating further development of dynamic geometry suitable for training and experimental design. In the history of CAD, there have been two, so to say, revolutions. The first revolution is from the drawing on paper to drawing on the computer, the next is the consequence of the development of tools in software that simplified the design process and that led to the simplification of the design process and the way of thinking 'from paper' to 'thinking within the software' (using a library of offered elements, copy-paste options and so on). Variational or parametric CAD has many similarities with dynamic geometric software. There is a possibility to change the parameters of CAD constructions in such a way that minor changes in parameters do not lead to the changes in the design. This can be used when, for example, there is a prototype of a construction that needs to be quickly adjusted or to compress 
data, when we need to store a large number of similar objects. It could also be used for the simple and quick construction of simple new models when starting from an approximate drawing that will be accurately plotted later on.

Numerous CAD applications support precise design. Among the most famous are: Catia, Rhinocerous, Autodesk Mechanical Desktop TM, SolidWorks TM, and many others. Digital 3D animation programmes came from CAD precision charting software, with the key difference being that their output image is an animation rather than a prototype. For this reason, the emphasis is on easy manipulation of objects in 3D space, and simplified controls for construction, which are especially important in modelling so-called organic models. The most popular programmes for computer animation are: Autodesk Softimage, Autodesk Maya, Autodesk 3ds Max, Cinema 4D, Blender and others. However, no teaching parametre (or dynamic) 3D tools are specifically adapted to students, in the same way as dynamic $2 \mathrm{D}$ geometric education programmes that are listed above, but they are available. The well known areas of 3D animation are: character animations, parametric animations (visualisations based on mathematical functions), medical and other scientific visualisations, dynamic simulations based on the laws of physics (fluids, fabrics, fur, solid body interactions, spraying, explosions and the similar), architectural visualisations and presentations of industrial design objects.

\section{Multimedia}

Multimedia is a very useful educational tool. The term multimedia is derived from the Latin words multus = many and medium $=$ intermediary or medium. Multimedia represents the combination of computerised images (moving or immobile), text, sound, animation, videos. If the text is included, these are brief instructions or explanations. The multimedia concept is presented by the interconnection of technical and software tools. Multimedia is a comprehensive media integration (Fig. 5). With the development of virtual technologies and software for multimedia programmes, multimedia interactivity has been achieved, which allows the user to control the way the information is displayed. The use of multimedia is suitable for geometrical education through interdisciplinary approach and the use of multimedia in geometrical education is encouraged.

There are various definitions of animation that are related to the root of the words, such as animus (Latin) meaning life, spirit, soul. Then anima - also of Latin origin - means life, spirit or breath. In Greek anemos means wind or breath, the proto-Indo-European ana has the meaning of breathe or to breathe. 
Animating means changing position, colour, shape, and so on of the objects or scenes that are subject to animation. Animation is metaphorically animated, it breathes life or spirit into virtual objects. Digital animation is also called computer animation as well as computer-generated images or performances CG (Computer Generated) and CGI (Computer Generated Imaging).

Computer animation involves computer-based calculations in which a sequence of images is produced which, in human perception, creates an illusion of movement. This computer calculation of the sequence image production is called rendering. There are several ways of digital animation: animation by placing key poses, parametric animation (and animation by establishing relationships) which are also nonlinear animations. This kind of animations are triggered using animation pics of the most common motion capture animation. In this paper, we have used a live capture animation, which involves recording during performance. ${ }^{30}$ Animations could be modelled in the sub-classes animation, which are called Scene Based Animation and Event Based Animation.

Computer animation can be 2D or 3D. Two-dimensional animation is based on the movement of elements in one plane, while the three-dimensional animation is based on the movement of three-dimensional representations of geometric objects in a three-dimensional virtual space. The 2D and 3D animation is called hybrid, and it implies the use of both concepts. It was this hybrid approach that is used in this paper to create animated multimedia for geometrical education.

The experience in the use of multimedia in the learning process demonstrates significant progress in the perception of huge possibilities for working with each model. The exchange of theoretical and practical knowledge among participants (teachers and students) in the distanced locations is one among many of the observed advantages of digital multimedia education. ${ }^{18}$
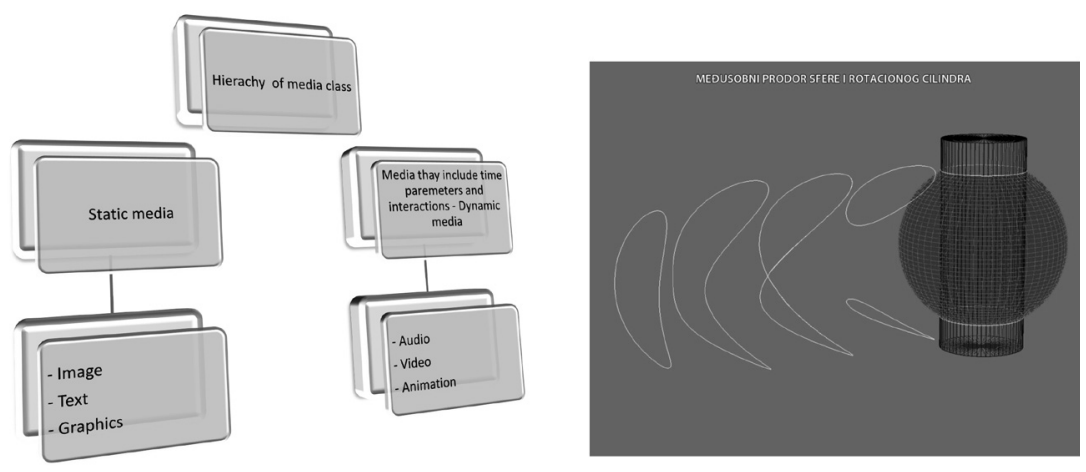

Figure 5. Media components 


\section{CONCLUSION}

The realisation of DVD in 3D software includes the process of making or working on and with shortform animations with concise text explanations by using principles of geometry. Students could enable themselves to repeat the same process and to continue to explore geometry topics with easy perception and learning. Short animation is done in a way that the whole process is directly recorded on 3D software, and every animation has text explanation that follows and explains the procedure and gives the basic definitions. Geometrical forms and their relationships are suitable for this type of learning and this kind of pedagogical methods could be well used. The application of this type of hybrid - transdisciplinary approach allows new directions for the geometrical content as well as the geometrical principles to be understood and learned in a virtual environment.

The advantages of using multimedia DVD in geometrical education are: stimulates interest, visually easier to remember, visual approach is better, better understood and mastered the material that is represented, better remembered when you see the process. Digital 3D animations are suitable for geometrical education. This kind of geometry learning tools offers new possibilities which allows students, teachers, artists, researchers, engineers, designers, etc. to be empowered in all field of work, from education to practice. The understanding of the dynamic and complex spatial relationships is enabled by using digital 3D animations. Students and teachers by using multimedia DVD could research the most diverse theoretical and practical problems. A new component in educational process is reperesented here by possibility to work interactively with objects in a simulated environment and to teach through movement, interaction and immediate response. Accordingly, the explanations of teachers' intentions are improved and greatly speeded up. Also, a new way of communication between teachers and students which was not dominant in conventional ways of teaching is achieved. The possibility of establishing a unique combination of collaboration and communication in interactive teaching process is transparent and direct. Digital 3D animations as dynamic geometry educational tools enable much better insight into the actual structure and construction. Through the movement directly is easier to learn about the changes in the construction of the structure. Tools for digital 3D animation in geometrical education open up a new perception of the tangible existence of the geometric forms which are all in motion, nothing is static. Compared to the conventional ways of teaching geometry, possible defects of using multimedia DVD in geometrical education are: the need for additional and more detailed explanation by the teacher, the lack of the text, the lack of the sound, without any previous knowledge it could be insufficiently explained, it is not possible to use this tool in all circumstances and the need for assistive technology. Despite that, the expected result is anticipated in a move towards more effective and more simple educational process. 
NOTES

N.B.

Authors are supported by the Ministry of Education, Science and Technological Development of the Republic of Serbia, Project No. TP 36008.

Mario Carpo, "The Digital: From complexity to simplicity- and back," Serbian Architectural Journal (2014): 256-265. Available at: http://saj.rs/the-digital-from-complexity-to-simplicity-andback/.

M. Billilnghurst, ed. "Mixing Realities in Shared Space:An Augmented Reality Interface for Colaborative Computing," in Proceedings of IEEE International Conference og Multimedia and Exp (IEEE Press, 2000): 1641-1644, 2000.

Michael Hansmeyer and Benjamin Dillenburger, ’Digital grotesque - Towards a micro-tectonic architecture," Serbian Architectural Journal 5 (2012): 194-201. Available at: http://saj.rs/wpcontent/uploads/2016/11/SAJ-2013-02-M-Hansmeyer-B-Dillenburger.pdf 2012.

F., Parke, Visualization Science (Texas A and M Univesity, Architecture). Available at: www.tamu. edu.

J.T., Todd., "The Visual Perception of 3D Shape," Trends in Cognitive Sciences Vol.8, Issue 3 (2004): 115-121.

I., Howard and W., Templeton, Human Spatial Orientation (New York: Wiley, 1966).

J. J., Gibson, The perception of the visual world (Oxford, England: Houghton Mifflin, 1950): 242.

Michael Hansmeyer and Benjamin Dillenburger, "Digital grotesque - Towards a micro-tectonic architecture,".

R., Boulic and O., Renault, 3D Hierarchies for Animation, New Trends in Animation and Visualization (Wiley professional Computing, 1991).

Ibid.

C., Leopold, R.A., Gorska and S.A. Sorby, "International Experiences in Developing the Spatial Visualisation Abilities of Engineering Students, " in Proceedings of ${ }^{\text {th }}$ Interanational Conference on Geometry and Graphics, pp.81-91, Johannesburg, South Africa, 2000.

M., Husty, 'Editorial, ’ IBDG Informationsblatter der Geometrie, vol.22 (2003): 1.

U.H., Kortenkamp, Foundation of Dynamic Geomery (PhD Dissertation Swiss Federal Institute of Technology, Zurich, Switzerland, 1999).

C., Laborde, "The computer as part of the learning environment: geometry," in The case of Learning from computers, mathematics education and technology, eds. C. Keitel and K. Ruthven, (Berlin: Springer, 1993), 48-67.

N., Jackiw, The Geometer's Sketchpad Version 3 (Berkeley: Key Curriculum Press, 1995).

J., Richter-Gebert and U. H., Kortenkamp, The Interactive Geometry Software Cinderella, Version 1.2 (Interactive Geometry on Computers), 1999.

R.,Mechling, EUKLID DynaGeo von innen - ein Blick hinter die Kulissen, http://www.dynageo. de, 2000 .

Johan Bettum, "Forms of saturation. Discreet and continuous events in architectural design," Serbian Architectural Journal 5 (2013): 170-193. Available at: http://saj.rs/wp-content/uploads/2016/11/ SAJ-2013-02-J-Bettum.pdf. 
Anđus, V., Metodologija istraživanja, poslediplomske studije. Građevinski fakultet Univerziteta u Beogradu, 2000.

Bettum, Johan. "Forms of saturation. Discrete and continuous events in architectural design." Serbian Architectural Journal 5/2 (2013): 170-193. Available at: http://saj.rs/wp-content/ uploads/2016/11/SAJ-2013-02-J-Bettum.pdf.

Billilnghurst, M.,et al.Mixing Realities in Shared Space:An Augmented Reality Interface for Colaborative Computing, Proceedings of IEEE International Conference og Multimedia and Exp, IEEE Press, pp.1641-1644, 2000.

Boulic, R., and O., Renault. 3D Hierarchies for Animation, New Trends in Animation and Visualization. Wiley professional Computing, 1991.

Brajkovic, J., B. Jović, Challenges of human body in new media space (Relations of human body and architectural space in the age of new media and technologies) Proceedings Moscow, November 18-21, 2014. International Scientific Youth Conference, Peoples Friendship University of Russia, Strength, creep and destruction of building and mechanical materials and structures, ISBN 9785-209-06240-0,UDK 624.04:621:691(063) 2014.

Carpo, Mario. "The Digital: From complexity to simplicity - and back." Serbian Architectural Journal (2014): 256-265. Available at: http://saj.rs/the-digital-from-complexity-to-simplicityand-back/.

Cucakovic, A., N. Teofilovic, B. Jovic. "Digital modeling of free forms structures at experimental design." Zbornik The Industrial Art and Design Issue No 12. The Interdepartmental Collection of Proceedings of SED-13, 10th Crimean International Scientific - Practical Conference, Geometrical and Computer Simulation: Safe Energy, Ecology, Design. Crimea, Simferopol, 7-10 October 2013. Ukraine Association for Applied Geometry. Kyiv. pp. 104-108. ISSN 2221-9293. UDK 514.18, 2013

Čučaković,A., B. Jović, Optional Course Engineering Graphics On Department For Landscaping Architecture At The Faculty Of Forestry, University Of Belgrade, International Conference SUNGIG moNGeometrija 2010, 24-27. June, 2010. godine, Belgrade, Serbia.

Čučaković A., M. Nestorović and B. Jović. Stereo perspective $14^{\text {th }}$ ICGG, Kyoto, Japan, 4-8 Aug 2010.

Čučaković A., M. Nestorović and B. Jović. Contemporary principles of geometrical modeling in education, Abstracts - 2nd Croatian Conference of Geometry and Graphics Scientific-Professional Colloquium of CSGG, pp. 10-11, Šibenik, Croatia, 5.-9., September 2010.

Čučaković A., B. Jović. "Constructive Geometry Education by Contemporary Technologies" Serbian Architectural Journal 3 (2011): 164-183.

Čučaković, A., N. Teofilović and B. Jović. 'Geometrijska edukacija primenom principa i alata 3D animacije." multimedijalni DVD, Arhitektonski fakultet Univerziteta u Beogradu, Beograd, 2013.

Čučaković, A., N. Teofilović and B. Jović. ' 'Descriptive Geometry Education by Using Multimedia Tools." Proceedings of the $16^{\text {th }}$ International Conference on Geometry and Graphics (ICGG 2014), (pp. 262-265), ISBN 978-3-902936-46-2, Innsbruck, Austria, August 4-8, 2014.

Gibson, J. J. The perception of the visual world. Oxford, England: Houghton Mifflin., 1950.

Hansmeyer, Michael and Dillenburger, Benjamin. "Digital grotesque - Towards a micro-tectonic architecture." Serbian Architectural Journal 5 (2013): 194-201. Available at: http://saj.rs/wpcontent/uploads/2016/11/SAJ-2013-02-M-Hansmeyer-B-Dillenburger.pdf.

Howard, I., and W. Templeton. Human Spatial Orientation. Wiley, New York 1966.

Husty, M., Editorial IBDG Informationsblatter der Geometrie, vol. 22, pp.1, 2003. 
Jackiw, N. The Geometer's Sketchpad Version 3. Berkeley: Key Curriculum Press, 1995.

Jović, Biljana. 'Geometrical education in domain of visualization and experimental design by virtual technologies." Doctoral dissertation, Faculty of Architecture, University of Belgrade, 2012.

Jović, B., N. Teofilović, A. Čučaković and M. Nestorović. ' 'Application of 3D animation principles and tools in geometrical education." TTEM 8/3 (2013).

Jović, Biljana, Aleksandar Čučaković and Miodrag Nestorović. Polyhedron construction by using multimedia tools in geometry education, 17th International conference on geometry and graphics, 4-8 August, 2016, Beijing, China, 2016.

Kortenkamp, U.H. ' Foundation of Dynamic Geomery.” PhD Dissertation. Swiss Federal Institute of Technology, Zurich, Switzerland, 1999

Laborde, C. "The computer as part of the learning environment: geometry, in the case of Learning from computers, mathematics education and technology." NATO ASI Series, vol. 121, C. Keitel and K. Ruthven, Eds. Berlin: Springer, pp. 48-67, 1993.

Leopold, C., Gorska, R.A., and Sorby, S.A., International Experiences in Developing the Spatial Visualisation Abilities of Engineering Students, in Proceedings of $9^{\text {th }}$ Interanational Conference on Geometry and Graphics, pp.81-91, Johannesburg, South Africa, 2000.

Mechling, R., EUKLID DynaGeo von innen - ein Blick hinter die Kulissen, http://www.dynageo. de, 2000.

Nestorović, M., Čučaković, A., Teofilović, N., Jović, B.: Geometrical Education by Using Multimedia Presentation, Scientific Proceedings of the $12^{\text {th }}$ International Conference on Engineering Graphics, ( ISBN 978-9934-507-30-4), pp. 163-169, BALTGRAF 2013, June 5-7, Riga, Latvia, 2013

Parke, F., Visualization Sciences, Texas A and M Univesity, Architecture, www.tamu.edu.

Richter-Gebert, J., and Kortenkamp, U. H., The Interactive Geometry Software Cinderella, Version 1.2 (Interactive Geometry on Computers), 1999.

Stanney, K.M., editor: Handbook of Virtual Environments: Design, Implementation and Application, Edited by University of Central Florida, Lawrence Erlbaum Associates, Mahwah, NJ., 2002.

Todd., J.T.,The Visual Perception of 3D Shape, Trends in Cognitive Sciences, Vol.8, Issue 3, pp.115121, Ohio State Univesity, Ohio, USA, 2004. 


\section{PREDNOSTI UPOTREBE 3D ANIMACIJE U GEOMETRIJSKOJ EDUKACIJI} Aleksandar Čučaković, Biljana Jović

U ovom radu je predstavljen je interdisciplinarni pristup upotrebe tehnologija novih medija. Rezultati istraživanja su prikazani kroz metodologiju upotrebe alata multimedije kao i primenu iste u geometrijskoj edukaciji. Metodologija korišćena u ovom radu proizašla je preklapanjem i prožimanjem različitih disciplina, kao što su: arhitektura, prostorni sistemi, nacrtna geometrija i kompjuterska animacija. Multimedijalne geometrijske konstrukcije predstavljaju dinamički vizualni edukativni sadržaj namenjen studentima tehničkih i umetničkih fakulteta. Multimedijalni DVD nosi naziv: "Geometrijska edukacija primenom principa i alata 3D animacije". Geometrijska edukacija omogućava razvoj razumevanja prostora, prostorne percepcije kao i sposobnosti predstavljanja prostornih formi. Crtež nije cilj geometrijske edukacije. Cilj ovog rada je pojednostavljivanje percepcije geometrijskih konstrukcija što je upotrebom metodologije predstavljene u ovom radu sasvim moguće.

KLJUČNE REČI: GEOMETRIJSKA EDUKACIJA, 3D ANIMACIJA, VIZUALIZACIJA, 3D SOFTVERI

\section{EKRANSKO-MEDIJSKI INTERFEJSI I SREDINE}

Jelena Brajković, Miodrag Nestorović

Pojava novih medija, kao i ubrzani razvoj njihovih raznovrsih formi, krajem dvadesetog i početkom dvadeset prvog veka, radikalno je uticao na mnoge aspekte, kako ljudskog svakodnevnog života, tako i savremene arhitektonske prakse. Pojava novih medija uslovila je pojavu novih tipova prostora u arhitekturi, koji se mogu nazvati i sredinama, koje se zasnivaju, koliko na arhitektonskim, toliko i na principima novih medija. Ovakvi prostori su ekranskomedijske, interaktivne, kinetičke, biotehnološke sredine, kao i prostori lumino arhitekture, koji funkcionišu na principima karakterističnim za nove medije. Posebno značajno u arhitektonskom kontekstu jeste svojstvo i veliki potencijal novih medija da stvore ubedljive iluzije i simulacije, kao i proizvedu uveličane, kompozitne i virtuelne realnosti i prostore. Upravo virtuelni predstavlja jednu od najizazovnijih formi novomedijskog prostora. On je ujedno i najkompleksnija forma ekransko-medijskih sredina, toliko radikalno drugačija od prethodnih da se izdvaja u posebnu kategoriju. Međutim, pored toga što kroz svoju formu virtuelnih sredina, predstavljaju najnapredniji i najkompleksniji tip novomedijskog prostora, ekranski interfejsi u arhitekturi predstavljaju i korene, najstarije i najtipičnije forme medijske arhitekture. Ovaj članak analiziraće pojavu i razvoj ekranskih interfejsa u arhitekturi, osvrnuće se na njihove forme i modalitete, kao i uticaj na čovekove impresije u prostoru.

KLJUČNE REČI: EKRAN, INTERFEJS, MEDIJSKA, ARHITEKTURA 